\title{
Site of New Primary Melanoma
}

National Cancer Institute

\section{Source}

National Cancer Institute. Site of New Primary Melanoma. NCI Thesaurus. Code C158836.

A directive to specify the site of the new primary melanoma. 